\title{
Effect of isomalt consumption on faecal microflora and colonic metabolism in healthy volunteers
}

\author{
A. Gostner ${ }^{1}$, M. Blaut ${ }^{2}$, V. Schäffer ${ }^{1}$, G. Kozianowski ${ }^{3}$, S. Theis ${ }^{3}$, M. Klingeberg ${ }^{3}$, Y. Dombrowski ${ }^{1}$, \\ D. Martin ${ }^{3}$, S. Ehrhardt ${ }^{3}$, D. Taras ${ }^{2}$, A. Schwiertz ${ }^{2}$, B. Kleessen ${ }^{2}$, H. Lührs ${ }^{1}$, J. Schauber ${ }^{1}$, D. Dorbath ${ }^{1}$, \\ T. Menzel ${ }^{1}$ and W. Scheppach ${ }^{1}$ \\ ${ }^{1}$ Department of Medicine II, University of Würzburg, Josef-Schneider-Strasse 2, D-97080 Würzburg, Germany \\ ${ }^{2}$ German Institute of Human Nutrition Potsdam-Rehbrücke, Department of Gastrointestinal Microbiology, Arthur-Scheunert-Allee \\ 114-116, D-14558 Nuthetal, Germany \\ ${ }^{3}$ Suedzucker AG, Wormser Strasse 11, D-67283 Obrigheim/Pfalz, Germany
}

(Received 14 February 2005 - Revised 17 July 2005 - Accepted 1 August 2005)

\begin{abstract}
Due to its low digestibility in the small intestine, a major fraction of the polyol isomalt reaches the colon. However, little is known about effects on the intestinal microflora. During two 4-week periods in a double-blind, placebo-controlled, cross-over design, nineteen healthy volunteers consumed a controlled basal diet enriched with either $30 \mathrm{~g}$ isomalt or $30 \mathrm{~g}$ sucrose daily. Stools were collected at the end of each test phase and various microbiological and luminal markers were analysed. Fermentation characteristics of isomalt were also investigated in vitro. Microbiological analyses of faecal samples indicated a shift of the gut flora towards an increase of bifidobacteria following consumption of the isomalt diet compared with the sucrose diet $(P<0.05)$. During the isomalt phase, the activity of bacterial $\beta$-glucosidase decreased $(P<0 \cdot 05)$ whereas $\beta$-glucuronidase, sulfatase, nitroreductase and urease remained unchanged. Faecal polyamines were not different between test periods with the exception of cadaverine, which showed a trend towards a lower concentration following isomalt $(P=0.055)$. Faecal SCFA, lactate, bile acids, neutral sterols, N, $\mathrm{NH}_{3}$, phenol and $p$-cresol were not affected by isomalt consumption. In vitro, isomalt was metabolized in several bifidobacteria strains and yielded high butyrate concentrations. Isomalt, which is used widely as a low-glycaemic and low-energy sweetener, has to be considered a prebiotic carbohydrate that might contribute to a healthy luminal environment of the colonic mucosa.
\end{abstract}

Isomalt: Bifidobacteria: Microbial metabolism: Healthy volunteers: Fluorescence in situ hybridization

Isomalt (Palatinit ${ }^{\circledR}$ ) is used worldwide as a sugar replacer with technological properties comparable to those of sucrose. Chemically, isomalt is a mixture of the polyols $1-O-\alpha-\mathrm{D}-\mathrm{glu}-$ copyranosyl-D-mannitol and 6-O- $\alpha$-D-glucopyranosyl-D-sorbitol. It is derived from sucrose in two major processing steps: (i) the enzymatic rearrangement of sucrose $(2-O-\alpha-\mathrm{D}-$ glucopyranosyl-D-fructofuranose) into isomaltulose; (ii) the catalytic hydrogenation of isomaltulose into isomalt. Physiologically, isomalt is characterized as low in energy, non-cariogenic (Gehring \& Karle, 1981) and low-glycaemic (Petzoldt et al. 1982; Gee et al. 1991; Hütter et al. 1993). As shown in ileostomy patients, isomalt is slowly and only partly digested and absorbed in the upper gastrointestinal tract (Langkilde et al. 1994). Undigested and/or unabsorbed portions reach the colon and are fermented by the gut microflora (Bär, 1990). On the basis of various studies in animals and human subjects, Livesey (2003) suggested that the undigested and fermented fraction of ingested isomalt is approximately $90 \%$.

Non- or low-digestible saccharides such as fructo-oligosaccharides, inulin and sugar alcohols are potential prebiotics
(Cummings et al. 2001). This property is defined as follows: 'A prebiotic effect is a food-induced increase in numbers and/or activity predominantly of bifidobacteria and lactic acid bacteria in the human intestine' (Van Loo et al. 1999). Bifidobacteria and lactic acid bacteria are considered biomarkers of a well-balanced intestinal flora. In breast-fed infants the intestinal flora is dominated by bifidobacteria and lactobacilli, whereas the flora of classic formula-fed infants contains more bacteroides, clostridia and enterobacteriaceae (Balmer \& Wharton, 1989). Human milk contains numerous bifidogenic factors like non-absorbable oligosaccharides, which are probably responsible for the difference in the flora of infants fed human milk and formula (Edwards \& Prrett, 2002). In some gastrointestinal diseases such as irritable bowel syndrome (Pistoli et al. 2003) and Crohn's disease (Giaffer et al. 1991; Linskens et al. 2001) the counts of bifidobacteria and lactobacilli in faeces are reduced in comparison to healthy controls. Several preventive and therapeutic properties of bifidobacteria and lactic acid bacteria on antibioticassociated intestinal disorders, gastroenteritis, lactose intolerance, intestinal infections with Clostridium difficile 
and Helicobacter pylori or traveller's diarrhoea, inflammatory bowel diseases, irritable bowel syndrome and colon cancer have been discussed (Gibson \& Roberfroid, 1995; Marteau et al. 2002). The mechanisms of these beneficial effects are not yet fully understood. Besides biotope competition, immunomodulation and production of antibiotic agents, the barrier function against pathogens, inflammatory diseases and neoplasms could be explained by the metabolic characteristics of bifidobacteria and lactic acid bacteria. Bifidobacteria form a major group of saccharolytic bacteria in the colon. By fermenting carbohydrates they produce lactate and SCFA, which results in lower $\mathrm{pH}$ values in the colon lumen that are not tolerated by the majority of pathogens. A more acidic milieu also inhibits protein degradation and microbial enzymes that liberate potentially harmful substances such as $\mathrm{NH}_{3}$, phenol derivatives, metabolites of bile acids and neutral sterols. Although lactobacilli and bifidobacteria do not produce considerable amounts of butyrate, an increase in bifidobacteria is associated with a high butyrate production, probably in symbiosis with other colon bacteria (Cummings et al. 2001). This SCFA is the main energy source for colonocytes (Roediger, 1982) and has regulatory effects on the cell cycle (Velazquez et al. 1996). Numerous attempts have been made to modulate the bacterial microflora by administering probiotic bacterial strains or prebiotic carbohydrates; the latter serve as substrates for the endogenous gut flora as well as external probiotics (Bezkorovainy, 2001). Today, inulin and fructo-oligosaccharides are the best studied prebiotics with bifidogenic effects (Gibson et al., 1995; Tuohy et al. $2001 b$ ). The objective of the present study was to investigate if the widely used sweetener isomalt may also have prebiotic properties.

\section{Subjects and methods}

\section{Subjects and study design}

Twenty healthy volunteers were recruited for the trial. One volunteer dropped out because of tonsillitis, which required the administration of antibiotics. Nineteen volunteers (twelve women and seven men) aged 34.7 (SE 2.4) years (median 30.5 years, range 21-53 years) completed the study. The BMI of the women was 23.5 (SE 0.7 ) $\mathrm{kg} / \mathrm{m}^{2}$ (median $23.6 \mathrm{~kg} / \mathrm{m}^{2}$, range $20.8-28.6 \mathrm{~kg} / \mathrm{m}^{2}$ ) and of the men $25.8(\mathrm{SE}$ $1 \cdot 1) \mathrm{kg} / \mathrm{m}^{2}$ (median $24 \cdot 0 \mathrm{~kg} / \mathrm{m}^{2}$, range $23 \cdot 3-30 \cdot 2 \mathrm{~kg} / \mathrm{m}^{2}$ ). Volunteers did not take any antibiotics for at least 6 weeks prior to the start of the study, nor did they take laxatives, motilityaffecting medications or lipid-altering medications during the study. Exclusion criteria were a history of severe chronic disease, gastrointestinal diseases, severe abdominal discomfort, severe constipation, abnormal dietary habits, known or suspected lack of compliance with the study protocol and pathologic laboratory values except elevated blood lipids. All participants signed consent forms after written and oral information about the aim, course and potential hazards of the trial. The study was approved by the Ethics Committee of the Faculty of Medicine, University of Würzburg, Germany.

The study was conducted in a double-blind, placebo-controlled, cross-over design. During two 4-week study periods, volunteers consumed a controlled diet with a washout phase of 4 weeks between periods. The diets were almost isoenergetic (difference in energy intake approximately $200 \mathrm{~kJ} / \mathrm{d}$ ) and composed as a typical Western diet. They provided $46 \%$ energy as carbohydrate, $40 \%$ energy as fat, and $14 \%$ energy as protein. Dietary fibre intake in the diets was limited to $1.4 \mathrm{~g} / \mathrm{MJ}$. Mean daily energy intake was $8.8 \mathrm{MJ}$ $(2100 \mathrm{kcal})$ for women and $11.3 \mathrm{MJ}(2700 \mathrm{kcal})$ for men. A $7 \mathrm{~d}$ rotating menu including ready-to-eat foods (Eismann Tiefkühl-Heimservice, Mettmann, Germany) was used. Meals were weighed and packed in the university hospital's dietetic kitchen. All meals (breakfast, morning snack, lunch, afternoon snack and dinner) were given to the subjects to be eaten at home. Additional food was not allowed, and the volunteers were asked to consume the delivered portions completely. The diets were identical except that isomalt was added to one diet and sucrose to the other. Isomalt and sucrose were given in sweet foods (jam, biscuits, pudding, chocolate and candies) during the test periods in a randomized cross-over fashion. The dose was increased from $5 \mathrm{~g} / \mathrm{d}$ to $30 \mathrm{~g} / \mathrm{d}$ in the first week of each test phase. The test products were prepared and supplied by Suedzucker AG (Mannheim/Ochsenfurt, Germany). When significant weight loss $(2 \mathrm{~kg})$ in the course of the study was noted, the volunteers received a fibre-free formula diet (Biosorb; Pfrimmer Nutricia, Erlangen, Germany) to meet energy requirements. Water, tea, coffee were allowed ad libitum. Alcohol consumption was restricted to $500 \mathrm{ml}$ beer or $250 \mathrm{ml}$ wine per week. Sugar-free soft drinks were restricted to $500 \mathrm{ml}$ daily. The macronutrient composition of the diet was calculated with the software package Prodi expert 4.502 based on the NutriBase database (Wissenschaftliche Verlagsgesellschaft $\mathrm{GmbH}$, Stuttgart, Germany) and information from the label of the ready-toeat foods. The diet has been described in detail previously (Gostner et al. 2005).

Urine collections $(24 \mathrm{~h})$ were obtained at the start and at weekly intervals in both phases. From day 24 to day 28 of each study period, stools were collected for quantitative assessment. Each stool was collected separately in a plastic box and frozen in the laboratory freezer as soon as possible (within $2 \mathrm{~h}$ as described previously; Hylla et al. 1998) and stored at $-25^{\circ} \mathrm{C}$. After each study period, $5 \mathrm{~d}$ stool collections were pooled without additives by using a grinder and frozen at $-25^{\circ} \mathrm{C}$ until determination of lactate, SCFA, N, Ca, phosphate, phenol and $p$-cresol. For determination of bile acids and neutral sterols, aliquots of pooled faeces were lyophilized (Gamma IA apparatus; Christ, Osterode, Germany). For bacterial spectrum, stool spot samples were collected on $2 \mathrm{~d}$ in separate thin tubes without media. Volunteers were asked to bring the stool samples as soon as possible after defecation and to fill up the tube to avoid a head space. An aliquot was fixed in paraformaldehyde (see later) for analysis by fluorescence in situ hybridization (FISH) or in $0.9 \% \mathrm{NaCl}$ for conventional microbiological culture techniques within $1 \mathrm{~h}$. For determination of bacterial enzyme activities, stool specimens were collected in tubes with anaerobic media (PBS with $0.5 \mathrm{~g}$ cysteine/l and $10 \%$ glycerol, $\mathrm{pH} 7.4$ ) and stored at $-80^{\circ} \mathrm{C}$ until analysis. For polyamine analysis, faecal samples were frozen in liquid $\mathrm{N}_{2}$, lyophilized and stored at $-80^{\circ} \mathrm{C}$ until analysis. 
Faecal bacterial spectrum using conventional microbiological culture techniques and fluorescence in situ hybridization with $16 S / 23 S$ rRNA

For enumeration of faecal bacteria with conventional microbiological culture techniques, $200 \mathrm{mg}$ fresh stool specimen was weighed into a bottle containing $0.9 \% \mathrm{NaCl}$ and frozen at $-80^{\circ} \mathrm{C}$. Analyses of faecal bacteria after serial dilution of the faecal slurry and plating on selective and non-selective media and enumeration were done by a commercial laboratory.

For whole-cell FISH with species- and group-specific oligonucleotide probes targeted to $16 \mathrm{~S} / 23 \mathrm{~S}$ rRNA, $500 \mathrm{mg}$ fresh faecal sample was fixed in paraformaldehyde and absolute ethanol respectively and stored at $-25^{\circ} \mathrm{C}$ until analysis. Hybridization and enumeration were performed according to the method of Schwiertz et al. (2000) using a charge-coupled device video camera (SensiCam; PCO, Kelheim, Germany) and the software package KS400 (Carl Zeiss GmbH, Jena, Germany).

Total bacteria were enumerated using a mixture of bacteriadirected oligonucleotide probes for hybridization (Eub338, Eub297, Eub785, Eub1055, Eub1088; Kleessen et al. 2001). The following group-specific oligonucleotides were chosen: HGC69a, Gram-positive bacteria with a high DNA G + C content (Roller et al. 1994); LGC354 group, Gram-positive bacteria with a low DNA G $+\mathrm{C}$ content (Meier et al. 1999); Fprau645, Faecalibacterium prausnitzii group (Suau et al. 2001); Erec482, Clostridium coccoides-Eubacterium rectale-Ruminococcus group (Franks et al. 1998); Ecyl387, Eubacterium cylindroides group (Harmsen et al. 2002a); Bac303, Bacteroides/-Prevotella cluster (Manz et al. 1996); Bif164, Bifidobacterium spp. (Langendijk et al. 1995); Ato291, Atopobium, Coriobacterium and Eggerthella lenta (Harmsen et al. 2000); Lab158, Lactobacillus/Enterococcus (Harmsen et al. 1999); Gam42a, $\gamma$ subclass of proteobacteria (Manz et al. 1992); Ec1531, Escherichia coli (Poulsen et al. 1995); Chis150, Clostridium histolyticum group (Franks et al. 1998); Clit135, Clostridium lituseburense group (Franks et al. 1998); Rint1102, Roseburia intestinalis group (Hold et al. 2003).

\section{Faecal bacterial enzymes}

Thawed probes were mixed for 3 min using a vortex and glass beads $(3 \mathrm{~mm})$. The stool suspension was centrifuged ( $200 \boldsymbol{g}$ for $10 \mathrm{~min}$ at $4^{\circ} \mathrm{C}$ ) and the supernatant was used for enzyme assays as follows.

Faecal $\beta$-glucuronidase activity was assayed in duplicate using a colorimetric kit (kit no. 325-A; Sigma Chemical Co., St. Louis, MO, USA).

For $\beta$-glucosidase the enzyme reaction was run at $37^{\circ} \mathrm{C}$ in a total volume of $2 \mathrm{ml}$ composed of $0.1 \mathrm{ml}$ faecal suspension, $0.4 \mathrm{ml}$ p-nitrophenyl glucoside $(0.01 \mathrm{~mol} / \mathrm{l}$; Sigma Chemical Co.) and $1.5 \mathrm{ml}$ acetate buffer $(0.1 \mathrm{~mol} / \mathrm{l}, \mathrm{pH} 7 \cdot 4)$. After 0 , 20, 40 and $60 \mathrm{~min}$ of incubation, the reaction was stopped by adding $1 \mathrm{ml}$ of a $1: 1$ mixture of glycine buffer $(0 \cdot 1 \mathrm{~mol} / 1$, $\mathrm{pH}$ 12) and distilled water to $0.2 \mathrm{ml}$ of the reaction mixture. The $p$-nitrophenol liberated was measured photometrically at $405 \mathrm{~nm}$.

Faecal sulfatase activity was assayed under similar conditions by using $0.4 \mathrm{ml} p$-nitrophenyl sulfate $(0.1 \mathrm{~mol} / \mathrm{l}$; Sigma Chemical Co.), $0.4 \mathrm{ml}$ faecal suspension and $1.2 \mathrm{ml}$ acetate buffer. Readings of liberated p-nitrophenol sampled after 0,30 and $60 \mathrm{~min}$ were taken at $405 \mathrm{~nm}$.

Faecal nitroreductase activity was measured according to the method of Wise et al. (1982) with minor modifications.

All the enzyme activities were calculated for the linear reaction range by using standard curves for each indicator (phenolphthalein, $p$-nitrophenol), and expressed as $\mu$ mol liberated indicator/h per $\mathrm{g}$ fresh faeces and as total daily enzyme activity $(\mu \mathrm{mol} \cdot \mathrm{h} / \mathrm{d})$.

Faecal urease activity was assayed in duplicate using a colorimetric kit (Ammonia-Kit 171; Sigma Chemical Co.) with minor modifications. Enzyme activity was expressed as $\mu \mathrm{mol}$ liberated $\mathrm{NH}_{3} / \mathrm{h}$ per $\mathrm{g}$ fresh faeces and as total daily enzyme activity $(\mu \mathrm{mol} \cdot \mathrm{h} / \mathrm{d})$ after subtraction of endogenous $\mathrm{NH}_{3}$.

\section{Faecal pH, SCFA and lactate}

Faecal $\mathrm{pH}$ was measured with a microprocessor $\mathrm{pH}$ meter (WTW, Weilheim, Germany) in triplicate in the pooled faecal samples.

SCFA were determined after conversion into their methyl esters using headspace GC (HP 6890 gas chromatograph; Agilent and PerkinElmer HS 40 XL headspace sampler; Agilent, Waldbronn, Germany) and a capillary fused silica column (PerkinElmer Elite 1701, $50 \mathrm{~m} \times 0.23 \mathrm{~mm} \times 1.0 \mu \mathrm{m}$; Perkin Elmer, Rodgau, Germany) with flame ionization detection. The carrier gas was He. The temperature programme was $50^{\circ} \mathrm{C}$ for $0.3 \mathrm{~min}, 30^{\circ} \mathrm{C} / \mathrm{min}$ to $260^{\circ} \mathrm{C}, 260^{\circ} \mathrm{C}$ for $6 \mathrm{~min}$. The concentrations of SCFA were calculated based on peak area ratios according to the internal standard method using chloroacetic acid as standard solution.

Faecal lactate (D- and L-lactate) was determined using a lactate dehydrogenase enzyme test (kit no. 1112821; Roche, Mannheim, Germany). Faecal samples $(5 \mathrm{~g})$ were clarified with Carrez reagents $\left(5 \mathrm{ml} \mathrm{K} 4\left(\mathrm{Fe}(\mathrm{CN})_{6}\right) \cdot 3 \mathrm{H}_{2} \mathrm{O}(3.6 \mathrm{~g} / 100 \mathrm{ml})\right.$, $5 \mathrm{ml} \mathrm{ZnSO}_{4} \cdot 7 \mathrm{H}_{2} \mathrm{O}(7 \cdot 2 \mathrm{~g} / 100 \mathrm{ml}), \mathrm{NaOH}(2 \mathrm{~mol} / \mathrm{l})$ to $\left.\mathrm{pH} 8\right)$ and filtered. The photometric measurement was performed at a wavelength of $365 \mathrm{~nm}$.

\section{Stool fat, stool nitrogen and ammonia}

Aliquots of pooled faecal samples were stored at $-25^{\circ} \mathrm{C}$ until analysis. Stool fat was analysed according to the method of van de Kamer et al. (1949).

$\mathrm{N}$ in faecal samples was analysed according to the Kjeldahl method (EN 25663). $\mathrm{NH}_{3}$ was assayed in duplicate in $50 \mu \mathrm{l}$ faecal suspension (for preparation, see this page) using a colorimetric kit (Ammonia-Kit 171; Sigma Chemical Co.) after deactivation of endogenous urease activity at $80^{\circ} \mathrm{C}$ for 20 min. $\mathrm{NH}_{3}$ concentration was expressed as $\mu \mathrm{mol} / \mathrm{g}$ wet weight and as total $\mathrm{NH}_{3}$ excretion/d.

\section{Faecal polyamines}

The polyamines putrescine, spermine, spermidine, cadaverine, histamine, N8-acetyl-permidine and N1-acetyl-spermine were analysed in lyophilized stool samples using HPLC according to the method of Noack et al. (1998). 


\section{Faecal bile acids and sterols}

Faecal bile acids and neutral sterols were analysed in dried faeces by GC-MS after derivatization of faecal bile acids to their n-butyl esters, directly in stools, followed by trimethylsilylation of the sterols and bile acids, according to the method of Batta et al. (1999). The determination was performed using the HP 6890 gas chromatograph (Agilent), an HP 5973 massselective detector and an HP-5 column (30 m, $0.25 \mathrm{~mm} \times 0.25 \mu \mathrm{m}$; Batta et al. 1999).

\section{Faecal and urinary phenol and p-cresol}

Phenol and $p$-cresol in urine and faeces were determined by GC after hydrolysis of the corresponding sulfate and glucuronic esters. The determination was performed by using the HP 6890 gas chromatograph with a Zebron ZB-5 column $(60 \mathrm{~m}$, $0.25 \mathrm{~mm}$ inner diameter, film thickness $0.25 \mu \mathrm{m}$; Phenomenex, Aschaffenburg, Germany) and with $\mathrm{He}$ as carrier gas. Split ratio was $10: 1$ at a constant flow rate of $1.4 \mathrm{ml} / \mathrm{min}$. Initial injector temperature was $40^{\circ} \mathrm{C}$ for $1 \mathrm{~min}, 10^{\circ} \mathrm{C} / \mathrm{min}$ to $230^{\circ} \mathrm{C}$. Temperature programme (column oven) was $50^{\circ} \mathrm{C}$ for $0.01 \mathrm{~min}, 680^{\circ} \mathrm{C} / \mathrm{min}$ to $250^{\circ} \mathrm{C}$ (flame ionization detector, $350^{\circ} \mathrm{C}$ ). The concentrations of the phenols were calculated based on peak area ratios according to the internal standard method with $o$-cresol as standard.

\section{In vitro experiments}

In vitro fermentation experiments with mixed human gut bacteria. Freshly voided mixed faeces of three volunteers were used to prepare a $10 \%(\mathrm{w} / \mathrm{v})$ faecal slurry in anaerobic phosphate buffer $(50 \mathrm{~mm}, \mathrm{pH} 7 \cdot 0,0.5 \mathrm{~g}$ cysteine- $\mathrm{HCl} / \mathrm{l})$. Batch culture in vitro fermentations was carried out under anaerobic conditions for $28 \mathrm{~h}$ at $37^{\circ} \mathrm{C}$ under slight stirring with $1 \%$ faecal slurry in the following basic medium: tryptone $1.5 \mathrm{~g}$, yeast extract $1.0 \mathrm{~g}, \mathrm{KH}_{2} \mathrm{PO}_{4} 0.24 \mathrm{~g}, \mathrm{Na}_{2} \mathrm{HPO}_{4} 0.24 \mathrm{~g}$, $\left(\mathrm{NH}_{4}\right)_{2} \mathrm{SO}_{4} \quad 1.24 \mathrm{~g}, \quad \mathrm{NaCl} \quad 0.48 \mathrm{~g}, \quad \mathrm{MgSO}_{4} \cdot 7 \mathrm{H}_{2} \mathrm{O} \quad 0.10 \mathrm{~g}$, $\mathrm{CaCl}_{2} \cdot 2 \mathrm{H}_{2} \mathrm{O} \quad 0.06 \mathrm{~g}, \mathrm{FeSO}_{4} \cdot 7 \mathrm{H}_{2} \mathrm{O} 2 \mathrm{mg}$, resazurin $1 \mathrm{mg}$, cysteine- $\mathrm{HCl} 0.5 \mathrm{~g}$, vitamin solution $0.5 \mathrm{ml}$, trace element solution $9.0 \mathrm{ml}, \mathrm{NaHCO}_{3} 2.0 \mathrm{~g}$ ad $1000 \mathrm{ml} \mathrm{H} \mathrm{H}_{2} \mathrm{O}$, pH 7.0, with or without $0.5 \%(\mathrm{w} / \mathrm{v})$ isomalt. The fermentation experiments were performed five times in duplicate. At different time intervals, samples of fermentation broth were centrifuged for $10 \mathrm{~min}$ at $12000 \mathrm{~g}$ at $4^{\circ} \mathrm{C}$ and subsequently sterile-filtered. Cell-free supernatants were kept at $-20^{\circ} \mathrm{C}$. The analysis of SCFA was performed by headspace GC as described earlier. Residual isomalt was analysed by high-pH anion-exchange chromatography with pulsed amperometric detection on a CarboPac-PA1 column (Dionex, Idstein, Germany) (Na-acetate gradient $1-27 \%, 30 \mathrm{~min}$, room temperature, flow rate of $1 \mathrm{ml} / \mathrm{min}$ ).

Fermentation experiments with human gut bifidobacteria. Bifidobacterium adolescentis (DSM 20083, DSM 20086, DSM 20087), Bifidobacterium angulatum (DSM 20098, DSM 20225), Bifidobacterium breve (DSM 20213), Bifidobacterium catenulatum (DSM 20103, DSM 20224), Bifidobacterium infantis (DSM 20223) and Bifidobacterium pseudocatenulatum (DSM 20438) were obtained from the Deutsche Sammlung von Mikroorganismen und Zellkulturen (Braunschweig, Germany). Bifidobacteria were grown anaerobically in 10-ml Hungate tubes on the following medium: peptone $10 \mathrm{~g}$, meat extract $5 \mathrm{~g}$, yeast extract $5 \mathrm{~g}$, $\mathrm{Na}_{2} \mathrm{HPO}_{4} 1.44 \mathrm{~g}, \mathrm{NaH}_{2} \mathrm{PO}_{4} 0.24 \mathrm{~g}, \mathrm{KH}_{2} \mathrm{PO}_{4} 6 \mathrm{~g}$, Tween-80 $1 \mathrm{~g}$, resazurin $1 \mathrm{mg}$, cysteine $-\mathrm{HCl} 0.5 \mathrm{~g}$, vitamin solution $0.5 \mathrm{ml}$, trace element solution $9.0 \mathrm{ml}, \mathrm{NaHCO}_{3} 2.0 \mathrm{~g}$, carbohydrate (isomalt or glucose) $10 \mathrm{~g}$ ad $1000 \mathrm{ml} \mathrm{H} \mathrm{H}_{2} \mathrm{O}, \mathrm{pH} 7 \cdot 0$. The medium was inoculated with an exponential culture $(1 \mathrm{ml})$ and incubated for $48 \mathrm{~h}$ at $37^{\circ} \mathrm{C}$. The fermentation experiments were performed in duplicate. Preparation and analysis of the culture supernatants for residual carbohydrate, acetate and lactate were performed as described earlier. Growth was monitored at $578 \mathrm{~nm}$ using a Hitachi 2000 spectrophotometer (Hitachi, Tokyo, Japan).

\section{Statistical analyses}

Values are given as means with their standard errors. The nonparametric Wilcoxon rank-sum test for paired data was used for comparisons. Correlations were obtained by Pearson's test. Analyses were performed using SigmaStat for Windows, version 2.03 (SPSS Inc., Chicago, IL, USA). Differences were considered significant at $P<0 \cdot 05$.

\section{Results}

Subjects

Nineteen volunteers completed the study. Consumption of $30 \mathrm{~g}$ isomalt daily in food was well tolerated. Compliance of the volunteers was confirmed by urinary mannitol excretion (Gostner et al. 2005).

\section{Faecal microflora}

Total bacterial counts, per g faeces wet weight and per d, analysed by the FISH technique, did not differ between the two test periods. However, there were differences with regard to counts of certain bacterial groups (Tables 1 and 2).

Using conventional microbiological culture technique on selective media, counts of bifidobacteria were significantly higher $(P<0.01)$ with isomalt consumption compared with sucrose (Table 1). As shown in Fig. 1, growth stimulation of bifidobacteria was confirmed using the FISH method. Compared with sucrose, the proportion of bifidobacteria increased by $65 \%(P<0.05)$ and total bifidobacteria cell counts by $47 \%$ $(P<0.05$; Fig. 1$)$. The mean faecal counts of bifidobacteria were $29 \%$ higher after isomalt than after sucrose consumption, but this figure did not reach statistical significance (Table 2).

Cell counts of lactobacilli, bacteroides, E. coli and enterococci reported by conventional culture techniques were not different between the test periods (Table 1). FISH analysis also showed a significant proportional increase of the atopobium group $(P<0.05)$ and of actinobacteria (Gram-positive bacteria with high $\mathrm{G}+\mathrm{C}$ DNA content; $P<0.01)$, together with higher cell counts of actinobacteria $(P<0 \cdot 05)$. Fewer cell counts of Roseburia intestinalis (counts/g faeces wet weight and counts/d: $P<0.01$ and $P<0 \cdot 05$, respectively) and of Gram-positive bacteria with low $\mathrm{G}+\mathrm{C}$ content (counts/d: $P<0.05$ ) as well as of bacteroides species (counts/g faeces wet weight: $P<0.05$ ) were seen (Table 2 ). 
Table 1. Mean bacterial counts (cfu $\times 10^{8} / \mathrm{g}$ faeces wet weight) and counts $/ \mathrm{d}$ (cfu $\times 10^{9} / \mathrm{d}$ ) determined by conventional culture methods in stool samples of nineteen healthy volunteers after 4 weeks' consumption of either $30 \mathrm{~g}$ isomalt or $30 \mathrm{~g}$ sucrose daily

(Mean values with their standard errors)

\begin{tabular}{|c|c|c|c|c|c|c|c|c|}
\hline \multirow[b]{2}{*}{ Genus } & \multicolumn{2}{|c|}{$\begin{array}{l}\text { Isomalt (counts/g } \\
\text { wet weight) }\end{array}$} & \multicolumn{2}{|c|}{$\begin{array}{c}\text { Sucrose (counts/g } \\
\text { wet weight) }\end{array}$} & \multicolumn{2}{|c|}{ Isomalt (counts/d) } & \multicolumn{2}{|c|}{$\begin{array}{l}\text { Sucrose } \\
\text { (counts/d) }\end{array}$} \\
\hline & Mean & SE & Mean & SE & Mean & SE & Mean & SE \\
\hline Bifidobacteria & $50 \cdot 2^{\star \star}$ & $13 \cdot 6$ & $21 \cdot 2$ & 4.0 & $505 \cdot 8^{*}$ & $130 \cdot 7$ & $186 \cdot 6$ & $34 \cdot 3$ \\
\hline Bacteroides & $68 \cdot 2$ & $20 \cdot 8$ & $42 \cdot 7$ & $16 \cdot 5$ & 752.9 & $261 \cdot 2$ & $320 \cdot 3$ & $98 \cdot 3$ \\
\hline Escherichia coli & 0.2 & 0.1 & 0.1 & 0.1 & $2 \cdot 2$ & 0.9 & 0.9 & 0.3 \\
\hline Lactobacilli & 0.002 & 0.001 & 0.002 & 0.002 & 0.03 & 0.02 & 0.02 & 0.01 \\
\hline Enterococci† & 0.002 & 0.001 & 0.006 & 0.01 & 0.02 & 0.01 & 0.1 & 0.1 \\
\hline
\end{tabular}

cfu, colony-forming units.

Mean values were significantly different from those of the sucrose group (Wilcoxon test for paired data): ${ }^{*} P<0.05,{ }^{* *} P<0.01$. †n 9 .

For details of subjects and procedures, see p. 41.

Table 2. Mean bacterial counts (counts $\times 10^{9} / \mathrm{g}$ faeces wet weight), counts/d (counts $\times 10^{11} / \mathrm{d}$ ) and proportion (\%) of total bacteria determined by fluorescence in situ hybridization in stool samples of nineteen healthy volunteers after 4 weeks' consumption of either $30 \mathrm{~g}$ isomalt or $30 \mathrm{~g}$ sucrose daily (Mean values with their standard errors)

\begin{tabular}{|c|c|c|c|c|c|c|c|c|c|c|c|c|}
\hline Genus & \multicolumn{2}{|c|}{$\begin{array}{l}\text { Isomalt (counts/g } \\
\text { wet weight) }\end{array}$} & \multicolumn{2}{|c|}{$\begin{array}{c}\text { Sucrose } \\
\text { (counts/g wet } \\
\text { weight) }\end{array}$} & \multicolumn{2}{|c|}{$\begin{array}{l}\text { Isomalt } \\
\text { (counts/d) }\end{array}$} & \multicolumn{2}{|c|}{$\begin{array}{l}\text { Sucrose } \\
\text { (counts/d) }\end{array}$} & \multicolumn{2}{|c|}{$\begin{array}{c}\text { Isomalt } \\
\text { proportion (\%) }\end{array}$} & \multicolumn{2}{|c|}{$\begin{array}{c}\text { Sucrose } \\
\text { proportion (\%) }\end{array}$} \\
\hline Total microflora & 126 & 13 & 161 & 15 & 146 & 21 & 156 & 21 & 100 & - & 100 & - \\
\hline Atopobium group & $2 \cdot 8$ & 0.4 & 1.7 & 0.2 & $3 \cdot 1$ & 0.6 & 1.8 & 0.3 & $2 \cdot 7^{\star}$ & 0.4 & 1.3 & 0.2 \\
\hline Bacteroides, Prevotella & $18 \cdot 3^{\star}$ & $1 \cdot 8$ & $26 \cdot 8$ & $2 \cdot 5$ & $21 \cdot 0$ & 3.5 & $26 \cdot 4$ & $3 \cdot 7$ & $16 \cdot 2$ & $1 \cdot 8$ & $18 \cdot 2$ & $1 \cdot 7$ \\
\hline $\begin{array}{l}\text { Clostridium histolyticum } \\
\text { group } \ddagger\end{array}$ & 0.003 & 0.001 & 0.005 & 0.001 & 0.004 & 0.001 & 0.005 & 0.001 & 0.003 & 0.001 & 0.004 & 0.001 \\
\hline $\begin{array}{l}\text { Clostridium lituseburense } \\
\text { group§ }\end{array}$ & 0.004 & 0.001 & 0.003 & 0.001 & 0.005 & 0.001 & 0.003 & 0.001 & 0.004 & 0.001 & 0.003 & 0.001 \\
\hline Escherichia coli & 0.3 & 0.04 & 0.4 & 0.1 & 0.4 & 0.1 & 0.4 & 0.1 & 0.3 & 0.03 & 0.3 & 0.04 \\
\hline $\begin{array}{l}\text { Eubacterium cylindroides } \\
\text { cluster }\end{array}$ & 1.5 & 0.6 & $1 \cdot 3$ & 0.4 & $2 \cdot 1$ & 0.9 & $1 \cdot 6$ & 0.5 & $1 \cdot 1$ & 0.3 & $1 \cdot 1$ & 0.5 \\
\hline Eubacterium rectale cluster & $10 \cdot 3$ & $1 \cdot 3$ & $9 \cdot 8$ & 1.5 & $11 \cdot 7$ & 1.9 & $9 \cdot 4$ & 1.5 & $8 \cdot 6$ & $1 \cdot 2$ & $8 \cdot 0$ & 1.5 \\
\hline Proteobacteria $\gamma$-group $\dagger$ & 3.4 & 0.5 & $2 \cdot 7$ & 0.5 & $3 \cdot 7$ & 0.5 & $2 \cdot 7$ & 0.6 & $2 \cdot 4$ & 0.4 & $2 \cdot 4$ & 0.6 \\
\hline $\begin{array}{l}\text { Lactobacillus/Enterococcus } \\
\text { group\|l }\end{array}$ & $1 \cdot 0$ & 0.4 & 1.9 & 0.5 & 1.4 & $0 \cdot 7$ & $2 \cdot 1$ & 0.7 & $0 \cdot 8$ & $0 \cdot 2$ & 1.6 & 0.6 \\
\hline $\mathrm{Gram}^{+}$bacteria LGCף & 0.04 & 0.01 & 0.14 & $0 \cdot 1$ & $0 \cdot 1^{*}$ & 0.01 & $0 \cdot 2$ & 0.1 & 0.04 & 0.01 & $0 \cdot 1$ & 0.1 \\
\hline $\begin{array}{l}\text { Actinobacteria (Gram }{ }^{+} \\
\text {bacteria HGC) }\end{array}$ & $12 \cdot 0^{*}$ & $2 \cdot 3$ & $8 \cdot 0$ & $1 \cdot 6$ & $12 \cdot 1^{*}$ & $2 \cdot 4$ & $6 \cdot 7$ & $1 \cdot 0$ & $11 \cdot 0^{\star \star}$ & $2 \cdot 4$ & $5 \cdot 1$ & $1 \cdot 0$ \\
\hline Roseburia intestinalis & $0 \cdot 3^{\star \star}$ & $0 \cdot 1$ & 0.6 & $0 \cdot 1$ & $0.4^{*}$ & 0.19 & 0.6 & $0 \cdot 1$ & 0.3 & $0 \cdot 1$ & 0.5 & $0 \cdot 1$ \\
\hline
\end{tabular}

LCG, low $G+C$ content (of DNA), HGC, high $G+C$ content (of DNA).

Mean values were significantly different from those of the sucrose group (Wilcoxon test for paired data): ${ }^{*} P<0.05,{ }^{* \star} P<0.01$.

Number of determinations/samples: $\nmid n 18 ; \ddagger n 15 ; \S n 12 ; \| n 14 ; \uparrow n 10$.

For details of subjects and procedures, see p. 41.

\section{Faecal bacterial enzyme activity}

Total faecal $\beta$-glucosidase activity decreased significantly by $40 \%$ after isomalt consumption compared with sucrose $(P<0 \cdot 05)$. Activities of $\beta$-glucuronidase, sulfatase, nitroreductase and urease were not significantly modified by isomalt (Fig. 2).

\section{Faecal pH, SCFA and lactate}

Stool $\mathrm{pH}$ was similar in the isomalt $(6 \cdot 7$ (SE 0.1)) and sucrose test phases (6.6 (SE 0.1); NS). Faecal concentration (isomalt: 7.7 (SE 0.5) v. sucrose: 8.0 (SE 0.5$) \mathrm{mg} / \mathrm{g}$ faeces wet weight) and daily excretion (isomalt: 867.2 (SE 105.6) v. sucrose:
834.3 (SE 108.4) $\mathrm{mg} / \mathrm{d}$ ) of total SCFA showed no significant differences between test phases. The same also applied to faecal concentrations and daily excretions of the individual SCFA, i.e. acetic, propionic, n-butyric, iso-butyric, iso-valeric and n-valeric acids (data not shown). In both test phases acetate, propionate and butyrate were the main SCFA in stool samples, with a molar ratio of acetate:propionate:butyrate of 62:19:19 after the isomalt test phase. Faecal concentrations of D-lactate (isomalt: 0.28 (SE 0.11) v. sucrose: 0.28 (SE $0 \cdot 14) \mathrm{mg} / \mathrm{g}$ faeces wet weight) and L-lactate (isomalt: 0.22 (SE 0.07) $v$. sucrose: 0.21 (SE 0.09) $\mathrm{mg} / \mathrm{g}$ faeces wet weight) were similar in both test periods. 


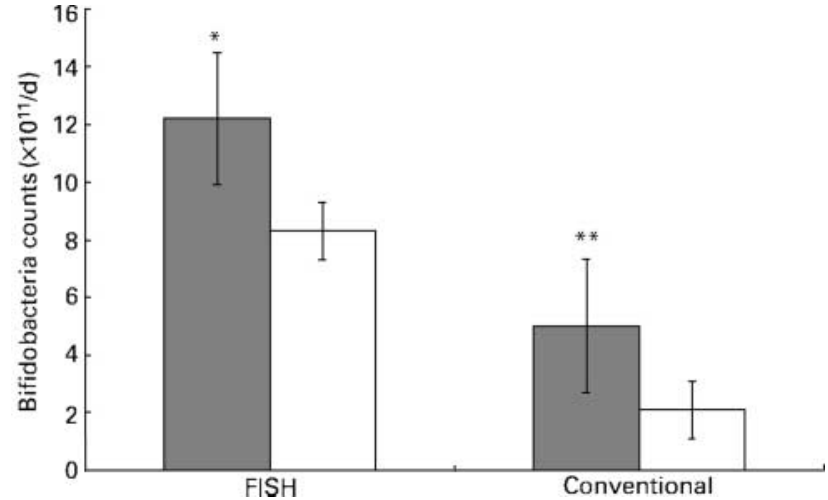

Fig. 1. Daily cell counts of bifidobacteria with isomalt consumption ( $\square$ ) and sucrose consumption $(\square)$ determined by fluorescence in situ hybridization (FISH) and conventional microbiological culture techniques. Values are means with their standard errors shown by vertical bars. Mean values were significantly different compared with the sucrose test phase (Wilcoxon test for paired data): ${ }^{\star} P<0.05,{ }^{\star \star} P<0.01$.

\section{Stool fat, nitrogen and ammonia}

Stool fat excretion was not affected by isomalt consumption compared with sucrose (percentage of stool fat: 2.3 (SE 0.2) for isomalt $v .2 .5(\mathrm{SE} 0.3)$ for sucrose, NS; daily stool fat excretion: $2 \cdot 1(\operatorname{SE} 0 \cdot 2) \mathrm{g} / \mathrm{d}$ for isomalt $v .2 \cdot 3(\operatorname{SE~} 0 \cdot 2) \mathrm{g} / \mathrm{d}$ for sucrose, NS).

Faecal $\mathrm{N}$ excretion did not differ between isomalt and sucrose test periods ( $\mathrm{N}$ concentration: 13.6 (SE 1.0$) \mathrm{mg} / \mathrm{g}$ faeces wet weight for isomalt $v .14 .1$ (SE 0.7$) \mathrm{mg} / \mathrm{g}$ faeces wet weight for sucrose, NS; daily $\mathrm{N}$ excretion: 1.4 (SE 0.1) $\mathrm{g} / \mathrm{d}$ for isomalt $v .1 .4$ (SE 0.1) g/d for sucrose, NS).

$\mathrm{NH}_{3}$ concentration and daily excretion were 11 and $20 \%$ lower, respectively, with isomalt, although differences between isomalt and sucrose were not significant $\left(\mathrm{NH}_{3}\right.$ concentration: 27.7 (SE 2.5) $\mu \mathrm{mol} / \mathrm{g}$ faeces wet weight for isomalt v. 31.1 (SE 3.0) $\mu \mathrm{mol} / \mathrm{g}$ faeces wet weight for sucrose, NS; $\mathrm{NH}_{3}$ excretion: 3071.7 (SE 417.3) $\mu \mathrm{mol} / \mathrm{d}$ for isomalt v. 3859.8 (SE 430.8) $\mu \mathrm{mol} / \mathrm{d}$ for sucrose, NS).

\section{Faecal polyamines}

Faecal concentration and daily excretion of the polyamines putrescine, spermidine and spermine were similar following consumption of either isomalt or sucrose (data not shown). There was a tendency towards lower cadaverine concentrations in the isomalt test period (isomalt: $0 \cdot 3$ (SE 0.1) $v$. sucrose: $0 \cdot 5 \quad(\mathrm{SE} \quad 0 \cdot 1) \quad \mu \mathrm{mol} / \mathrm{g}$ faeces wet weight, $P=0 \cdot 055)$. Putrescine and spermidine were detectable in all stool samples, whereas cadaverine was detectable in thirteen and spermine in three stool samples from both periods. The biogenic amines histamine, N8-acetyl-spermidine and N1-acetyl-spermine were found only sporadically.

\section{Faecal bile acids and neutral sterols}

Faecal concentration (isomalt: 11.1 (SE 0.9) v. sucrose: 11.5 (SE 1.0$) \mathrm{mg} / \mathrm{g}$ faeces dry weight, NS) and daily excretion of total bile acids (isomalt: 298.8 (SE 21.4) v. sucrose: 282.0 (SE 35.5$) \mathrm{mg} / \mathrm{d}$, NS) were similar in both test periods, as was faecal concentration (isomalt: 5.7 (SE 0.8) $v$. sucrose: $5.7(\mathrm{SE} 0.5) \mathrm{mg} / \mathrm{g}$ faeces dry weight) and daily excretion (isomalt: 163.8 (SE 22.3) v. sucrose: 143.1 (SE 20.5) mg/d) of total neutral sterols. Comparable concentration and daily excretion in both periods was also observed for individual bile acids (primary or secondary) and neutral sterols (data not shown).

\section{Faecal and urinary phenol and p-cresol}

Urinary concentration/excretion of $p$-cresol was comparable in the isomalt and sucrose phases. With regard to stool specimens, the concentration and excretion of phenol and $p$-cresol were similar in both experimental periods. Urinary phenol excretion decreased significantly during the sucrose diet whereas it remained unchanged during the test phase with isomalt. Consequently, urinary phenol excretion was significantly lower in week 4 of the sucrose test phase than in week 4 of the isomalt phase (Table 3 ).

A positive correlation was found between faecal and urinary phenol excretion with isomalt $(r 0.69, P<0.05)$ but not with

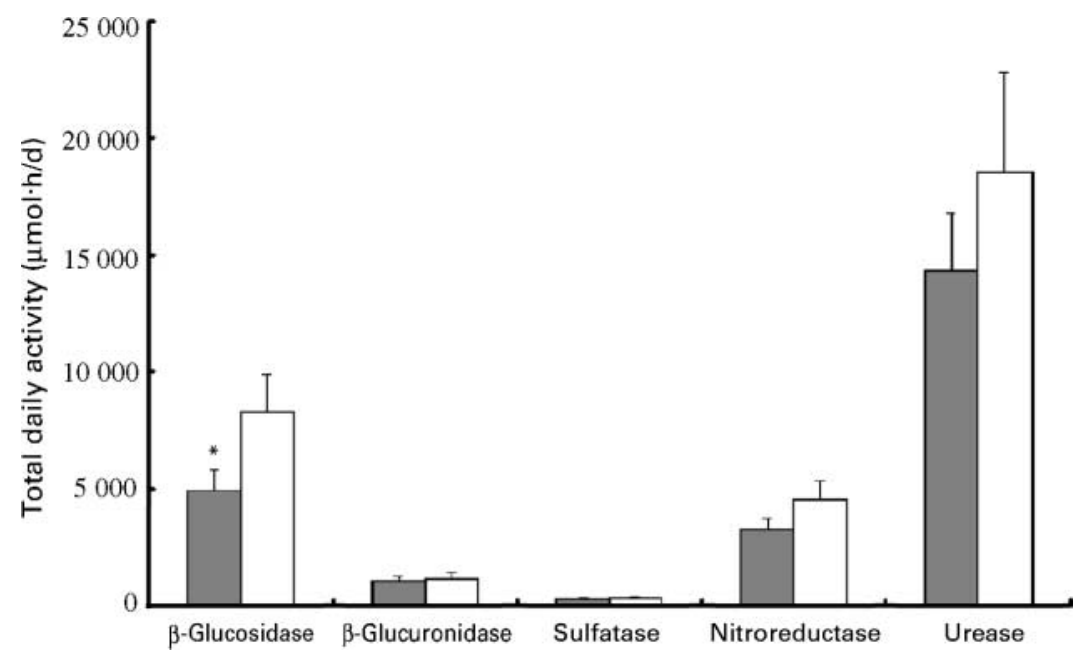

Fig. 2. Total daily faecal enzyme activities during isomalt consumption ( $\square$ ) and sucrose consumption ( $\square$ ). Values are means with their standard errors shown by vertical bars. Mean values were significantly different compared with the sucrose test phase (Wilcoxon test for paired data): ${ }^{\star} P<0.05$. 
Table 3. Faecal $(\mathrm{mg} / \mathrm{kg})$ and urinary $(\mathrm{mg} / \mathrm{l})$ concentration and faecal and urinary excretion $(\mathrm{mg} / \mathrm{d})$ of phenol and $p$-cresol in nineteen healthy volunteers consuming either $30 \mathrm{~g}$ isomalt or $30 \mathrm{~g}$ sucrose daily (Mean values with their standard errors)

\begin{tabular}{|c|c|c|c|c|c|c|c|c|c|}
\hline & \multirow[b]{3}{*}{ Week } & \multicolumn{4}{|c|}{ Concentration } & \multicolumn{4}{|c|}{ Excretion } \\
\hline & & \multicolumn{2}{|c|}{$\begin{array}{l}\text { Isomalt } \\
\text { (mg/l; /kg) }\end{array}$} & \multicolumn{2}{|c|}{$\begin{array}{l}\text { Sucrose } \\
\text { (mg/l; /kg) }\end{array}$} & \multicolumn{2}{|c|}{ Isomalt (mg/d) } & \multicolumn{2}{|c|}{ Sucrose $(\mathrm{mg} / \mathrm{d})$} \\
\hline & & Mean & SE & Mean & SE & Mean & SE & Mean & SE \\
\hline \multirow[t]{2}{*}{ Urinary phenol } & 0 & 9.5 & $3 \cdot 2$ & $6 \cdot 7$ & $2 \cdot 0$ & $10 \cdot 8$ & $3 \cdot 0$ & $9 \cdot 5$ & 1.8 \\
\hline & 4 & 8.9 & $3 \cdot 2$ & 3.7 & 0.8 & $11 \cdot 0$ & 3.5 & $5 \cdot 4^{*} \dagger$ & $1 \cdot 1$ \\
\hline \multirow[t]{2}{*}{ Urinary $p$-cresol } & 0 & $19 \cdot 4$ & 3.9 & $13 \cdot 8$ & $3 \cdot 7$ & $24 \cdot 1$ & $3 \cdot 3$ & $23 \cdot 6$ & $6 \cdot 3$ \\
\hline & 4 & 13.9 & $2 \cdot 0$ & 14.9 & $2 \cdot 6$ & $19 \cdot 8$ & $2 \cdot 9$ & $17 \cdot 9$ & $2 \cdot 1$ \\
\hline Faecal phenol & 4 & $5 \cdot 5$ & 1.4 & $6 \cdot 7$ & 1.5 & 0.58 & 0.13 & 0.63 & 0.14 \\
\hline Faecal $p$-cresol & 4 & $38 \cdot 8$ & 4.5 & $39 \cdot 3$ & $6 \cdot 2$ & $4 \cdot 1$ & 0.47 & 3.4 & 0.42 \\
\hline
\end{tabular}

Mean value was significantly different from that at baseline (Wilcoxon test for paired data): ${ }^{*} P<0.05$.

Mean value was significantly different from that of the isomalt phase (Wilcoxon test for paired data): $\uparrow P<0.05$.

For details of subjects and procedures, see p. 41 .

sucrose $(r 0.13)$, and not with $p$-cresol in both test phases (isomalt: $r 0 \cdot 4$; sucrose: $r 0 \cdot 3$ ). Faecal phenol excretion was negatively correlated with the mean transit time (as reported elsewhere, Gostner et al. 2005; $r-0.54, P<0 \cdot 05$ ). No correlations were found between mean transit time and $p$-cresol excretion with isomalt $(r$ 0.07) or between mean transit time and phenol and $p$-cresol in the sucrose test phase $(r-0.44$ and $r 0.43$, respectively).

\section{Utilization of isomalt by human gut bacteria in vitro}

To study the fermentation properties of isomalt escaping digestion in the small intestine and its metabolism by human gut bacteria, an in vitro fermentation assay was developed and extensively validated. Fig. 3 shows the data of in vitro fermentation assays with gut bacteria from mixed faecal samples of three human volunteers. Isomalt was degraded completely by human gut bacteria over a $14 \mathrm{~h}$ fermentation period, and the main SCFA formed were acetate, propionate and butyrate. Total SCFA concentration at the end of the fermentation was 35.6 (SE 3.3) $\mathrm{mmol} / \mathrm{l}$, while in the fermentation control (medium without supplemented carbohydrate) only $18.8 \mathrm{mmol} / \mathrm{l}$ was measured. A comparatively high concentration of butyrate was formed (14.2 (SE 1.8) mmol/l), which was more than that obtained with known butyrogenic substrates such as resistant starches (11.4 (SE 2.6) mmol/l, data not shown). An acidification of the medium to $\mathrm{pH} 6 \cdot 2$ ( $\mathrm{SE}$ $0 \cdot 3$ ) was observed at the end of the fermentation compared

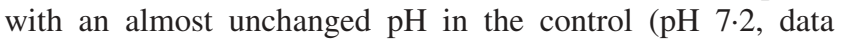
not shown).

\section{Fermentation experiments with human gut bifidobacteria}

As shown in Table 4, human bifidobacteria strains utilized isomalt and grew on a medium with isomalt as sole carbohydrate source. Some strains, e.g. B. adolescentis (DSM 20086), B. catenulatum (DSM 20103, 20224) and B. infantis (DSM 20223 ), metabolized isomalt almost completely. At the end of the fermentation experiment the isomalt content in the growth medium was reduced to less than $10 \%$ of the initial value and the concentration of SCFA in the medium increased to $60 \mathrm{mmol}$ acetate/l and $32 \mathrm{mmol}$ lactate/l. The optical density of these bacterial cultures at the end of the fermentation experiment was comparable to cell densities obtained with glucose as sole carbohydrate source (data not shown).

\section{Discussion}

The human colon harbours approximately $10^{11}-10^{12}$ bacterial cells per gram of colon content with more than 400 different species of bacteria. The composition of the intestinal microflora varies among individuals and has traditionally been

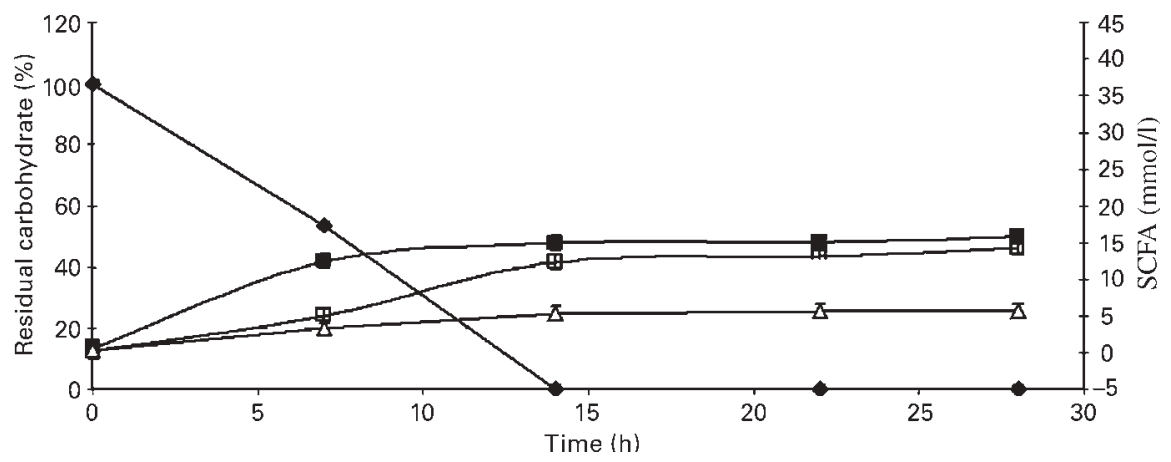

Fig. 3. In vitro fermentation of isomalt $(\diamond)$ into $\operatorname{SCFA}(\boldsymbol{\square}$, acetate; $\triangle$, propionate; $\square$, butyrate) by human gut bacteria. Values are means with their standard errors shown by vertical bars. 
Table 4. Fermentation experiments with human gut bifidobacteria strains

\begin{tabular}{|c|c|c|c|c|c|}
\hline Species & DSM no. & Acetate $(\mathrm{mmol} / \mathrm{l})$ & Lactate $(\mathrm{mmol} / \mathrm{l})$ & Residual isomalt (\%) & $O D_{578}$ \\
\hline \multirow[t]{3}{*}{ Bifidobacterium adolescentis } & 20083 & $47 \cdot 9$ & $23 \cdot 7$ & $19 \cdot 7$ & 1.9 \\
\hline & 20086 & $35 \cdot 7$ & $27 \cdot 6$ & $5 \cdot 5$ & $1 \cdot 8$ \\
\hline & 20087 & $45 \cdot 9$ & $20 \cdot 5$ & $23 \cdot 5$ & $2 \cdot 5$ \\
\hline \multirow[t]{2}{*}{ Bifidobacterium angulatum } & 20098 & $46 \cdot 5$ & 9.9 & $29 \cdot 0$ & 2.5 \\
\hline & 20225 & $35 \cdot 4$ & 4.4 & $49 \cdot 7$ & $2 \cdot 4$ \\
\hline Bifidobacterium breve & 20213 & $26 \cdot 1$ & $2 \cdot 6$ & $64 \cdot 3$ & $2 \cdot 0$ \\
\hline \multirow[t]{2}{*}{ Bifidobacterium catenulatum } & 20103 & $43 \cdot 1$ & $23 \cdot 1$ & $8 \cdot 3$ & 3.7 \\
\hline & 20224 & $57 \cdot 9$ & 31.9 & $3 \cdot 1$ & $4 \cdot 2$ \\
\hline Bifidobacterium infantis & 20223 & $59 \cdot 8$ & $21 \cdot 1$ & 8.5 & $3 \cdot 6$ \\
\hline Bifidobacterium pseudocatenulatum & 20438 & $42 \cdot 4$ & $17 \cdot 6$ & $21 \cdot 8$ & 1.5 \\
\hline
\end{tabular}

$O D_{578}$, optical density measured at $578 \mathrm{~nm}$; DSM, Deutsche Sammlung von Mikroorganismen and Zellkulturen.

thought to be very stable. However, it is now well recognized that the microflora of the intestine can be modulated by dietary intervention. A focus of many studies has been specific stimulation of the growth of resident bifidobacteria and lactobacillus species by feeding prebiotic low-digestible carbohydrates (Gibson \& Roberfroid, 1995).

The major novel finding of the present trial has been the prebiotic effect of isomalt, which is used widely as a low-glycaemic and low-calorie food sweetener. Using two independent methods (conventional microbiological culture techniques and FISH with $16 \mathrm{~S} / 23 \mathrm{~S}$ rRNA) we observed a significant increase in the faecal number and proportion of bifidobacteria by 47 and $65 \%$. To our knowledge this is the first study that demonstrates that isomalt has also bifidogenic effects. This finding was further confirmed by in vitro experiments demonstrating the utilization of isomalt by several isolated human bifidobacteria strains. In addition to changes in bifidogenesis, an increase in the proportion and counts of bacteria belonging to the atopobium cluster was observed in faecal samples. This cluster includes several bacterial species, e.g. lactic acid-producing coriobacteria. The higher proportion and cell counts of actinobacteria (Gram-positive bacteria with high $\mathrm{G}+\mathrm{C}$ DNA content) confirmed the increased counts of bifidobacteria and the atopobium cluster, as these are included therein. Proportions of other bacteria or bacteria groups were comparable in both periods and not affected by isomalt. Counts of the $R$. intestinalis group and of bacteroides (mean counts) were lower in the isomalt period. $R$. intestinalis represents a small group of the bacterial spectrum and also includes butyrate-producing bacteria species. In vitro fermentation with gut bacteria demonstrated that high butyrate concentrations are obtained from isomalt. Thus, lower counts obtained for the $R$. intestinalis group may indicate that bacteria of this group do not contribute considerably to the butyrate generation from isomalt.

An interesting question is how the bifidogenic effect of isomalt observed in the present trial compares with known prebiotics such as fructo-oligosaccharides and other lowdigestible carbohydrates. The increase in bifidobacteria of $0.3 \mathrm{log}$ cells/g faeces observed in the present study falls within the range reported by others (Gibson et al. 1995; Buddington et al. 1996; Kleessen et al. 1997; Menne et al. 1997; Alles et al. 1999; Bouhnik et al. 1999; Brighenti et al. 1999; Kruse et al. 1999; Zhong et al. 2000; Rao, 2001; Tuohy et al. 2001a,b; Harmsen et al. 2002b). In these studies, daily ingestion of 2.5 to $40 \mathrm{~g}$ low-digestible carbohydrates led to an increase in bifidobacteria of $0 \cdot 1-1 \cdot 3 \mathrm{log}$ cells/g faeces. Several authors found that the relative increase of faecal bifidobacteria in response to a prebiotic carbohydrate was highly dependent on the initial bacterial count (more pronounced prebiotic effect with low starting counts; Rao, 2001; Tuohy et al. $2001 b$ ). The magnitude of effect observed in the present study is equivalent to the $0.2-0.3 \mathrm{log}$ increase found in other trials with healthy volunteers and high initial counts of faecal bifidobacteria (Brighenti et al. 1999, Tuohy et al. 2001b; Harmsen et al. 2002b).

Some hydrolytic and reductive bacterial enzymes catalyse reactions that release (co)carcinogens or promoters of colon carcinogenesis. For example, $\beta$-glucuronidase and sulfatase activate potentially toxic substances such as bile acids by deconjugation of the non-toxic conjugated substrates. The enzyme $\beta$-glucosidase hydrolyses plant glycosides and releases toxic aglycons (Mallett et al. 1987). The formation of aromatic amines by nitroreductase causes the production of potentially genotoxic intermediates such as reactive $N$ hydroxy compounds (Wheeler et al. 1975). Cytotoxic $\mathrm{NH}_{3}$, which at high concentrations plays a role in hepatic encephalopathy, is produced by urease (Blei, 2000). There is evidence that a high-fibre diet could modulate microbial enzymatic activities (Johanson et al. 1990; Grasten et al. 2000). In the present study, total $\beta$-glucosidase activity was $40 \%$ lower at the end of the isomalt period compared with sucrose. Several mechanisms are possible for the observed reduction in faecal enzyme activity. The effect may be mediated by dilution effects, alterations in the composition of the intestinal microbial flora, modulation of the microbial environment such as $\mathrm{pH}$ value and substrate availability, or by direct or indirect substrate inhibition. In the present study a simple dilution effect is not likely, since specific activity and stool weight were not significantly altered by isomalt. As Bacteroides ovatus is known as a main producer of $\beta$-glucosidase (McBain \& Macfarlane, 1998), it is imaginable that the significant decrease in faecal bacteroide concentrations of about $32 \%$ was one cause of the reduction in $\beta$-glucosidase activity. However, some strains of bifidobacteria are also known to synthesize $\beta$-glucosidase (McBain \& Macfarlane, 1998, 2001).

There is a wide variety of bacterial metabolic processes in the human colon that may be influenced by nutritional factors, especially the intake of low-digestible carbohydrates. A more saccharolytic profile of the intestinal microflora with fermentation of carbohydrates in the colon is associated with 
production of SCFA and lactate. SCFA, especially butyrate, are essential for the maintenance of physiological colonocyte morphology and function (Scheppach, 1994; Scheppach et al. 2001). In the present study, however, the faecal concentrations or daily excretions of the following metabolites/end products seemed to be not affected by isomalt consumption.

SCFA, lactate and $\mathrm{pH}$ value in faeces were similar in both test periods. Nevertheless, in vitro fermentation experiments showed that isomalt is completely fermented by human intestinal bacteria and that this fermentation pattern results in an increase in SCFA, especially butyrate, and a decrease in $\mathrm{pH}$. The divergence between in vivo and in vitro is plausible because of the high absorption rates of SCFA in the colon. Thus, differences in SCFA production and $\mathrm{pH}$ in the colon between isomalt and sucrose may not be detectable in faeces.

In the present study faecal $\mathrm{N}$ was similar in both study periods. This observation differs from results of a study in pigs where the feeding of isomalt led to an increase of faecal N (van Weerden \& Huisman, 1993). It has been proposed that the fermentation of carbohydrates stimulates bacterial proliferation and, thus, the fixation of $\mathrm{N}$ in bacterial matter. The finding for faecal $\mathrm{N}$ seems to be plausible, as there was no increase in the total bacteria counts in our study.

According to Weber (1997), the incorporation of $\mathrm{N}$ in bacteria would also lower luminal $\mathrm{NH}_{3}$ concentrations. High concentrations of $\mathrm{NH}_{3}$ are cytotoxic and may promote colonic carcinogenesis (Lin \& Visek, 1991). In the present study faecal concentrations and daily output of $\mathrm{NH}_{3}$ were 11 and $20 \%$ less with isomalt, although this difference did not reach significance.

Considerable amounts of polyamines have been detected in the human colon (Benamouzig et al. 1997). While putrescine, spermidine and spermine can be synthesized by mucosal cells or luminal bacteria, cadaverine is exclusively of bacterial origin. In this study, a trend towards lower faecal cadaverine concentration was observed following ingestion of isomalt whereas the faecal excretion of other polyamines was comparable between the two test periods.

Phenol and $p$-cresol are metabolites of the bacterial fermentation of aromatic amino acids (phenylalanine, tyrosine) and may play a role in the initiation of colon (Bone et al. 1976) and bladder cancer (Bryan, 1971). They are partially absorbed and excreted in the urine. In the present study no differences in the faecal concentrations of phenol and $p$-cresol were shown. Daily urinary phenol excretion did not change during the isomalt test period whereas it was reduced during the test period with sucrose. This finding is difficult to explain because there is no evidence in the literature that sucrose may affect protein fermentation.

Faecal concentration and daily excretion of bile acids and neutral sterols were not affected by isomalt consumption. Despite research in this field it is still unclear whether neutral steroids and bile acids are involved in large bowel carcinogenesis. In previous human intervention studies with acarbose (Bartram et al. 1991) and resistant starch (Hylon VII; Hylla et al. 1998) our group has shown a reduction of faecal concentrations of secondary bile acids and neutral sterols. In accordance with the present study, Alles et al. (1999) found no effect of low-digestible carbohydrates.

In conclusion, the present study showed for the first time that the widely used sweetener isomalt is bifidogenic in healthy volunteers and is thus a candidate prebiotic carbohydrate that might contribute to a healthy gut flora and function. The extent of the bifidogenic effect obtained with isomalt was in good accordance with other studies examining prebiotic carbohydrates in healthy individuals with high initial bifidobacteria counts.

\section{Acknowledgements}

We thank Gerda Dusel, Elisabeth Kelber and Kerstin Backhaus for excellent technical assistance; Sabine Weber, Margit Arenz, ZAFES, Suedzucker AG, Offstein/Pfalz, Germany for development and preparation of the test products; Mrs Hoppe and the staff of the dietetic kitchen for kind cooperation.

This study was supported by Suedzucker AG, Mannheim/ Ochsenfurt, Germany.

\section{References}

Alles MS, Hartemink R, Meyboom S, Harryvan JL, Van Laere KM, Nagengast FM \& Hautvast JG (1999) Effect of transgalactooligosaccharides on the composition of the human intestinal microflora and on putative risk markers for colon cancer. Am J Clin Nutr $\mathbf{6 9}$, 980-991.

Balmer SE \& Wharton BA (1989) Diet and fecal flora of the new born: breast milk and infant formula. Arch Dis Child 64, $1672-1677$.

Bär A (1990) Factorial calculation model for the estimation of the physiological caloric value of polyols. In Proceedings of the International Symposium on Caloric Evaluation of Carbohydrates, pp. 209-257 [N Hosoxa, editor]. Tokyo: Research Foundation for Sugar Metabolism.

Batta AK, Salen G, Rapole KR, Batta M, Batta P \& Alberts ED (1999) Highly simplified method for gas-liquid chromatographic quantitation of bile acids and sterols in human stool. J Lipid Res 40, 1148-1154.

Bartram HP, Scheppach W, Heid C, Fabian C \& Kasper H (1991) Effect of starch malabsorption on fecal bile acids and neutral sterols in humans: possible implications for colonic carcinogenesis. Cancer Res 51, 4238-4242.

Benamouzig R, Mahé S, Luengo C, Rautureau J \& Tomé D (1997) Fasting and postprandial polyamine concentrations in human digestive lumen. Am J Clin Nutr 65, 766-770.

Bezkorovainy A (2001) Probiotics: determinants of survival and growth in the gut. Am J Clin Nutr 73, Suppl. 3, 99S-405S.

Blei AT (2000) Diagnosis and treatment of hepatic encephalopathy. Baillieres Best Pract Res Clin Gastroenterol 14, 959-974.

Bone E, Tamm A \& Hill M (1976) The production of urinary phenols by gut bacteria and their possible role in the causation of large bowel cancer. Am J Clin Nutr 29, 1448-1454.

Bouhnik Y, Vahedi K, Achour L, Attar A, Salfati J, Pochart P, Marteau P, Flourie B, Bornet F \& Rambaud JC (1999) Shortchain fructo-oligosaccharide administration dose-dependently increases fecal bifidobacteria in healthy humans. J Nutr 129, $113-116$.

Brighenti F, Casiraghi C, Canzi E \& Ferari A (1999) Effect of consumption of a ready-to eat breakfast cereal containing inulin on the intestinal milieu and blood lipids in healthy male volunteers. Eur J Clin Nutr 53, 726-733.

Bryan GT (1971) The role of urinary tryptophan metabolites in the etiology of bladder cancer. Am J Clin Nutr 24, 841-847.

Buddington RK, Williams CH, Chen SC \& Witherly SA (1996) Dietary supplement of neosugar alters the fecal flora and decreases 
activities of some reductive enzymes in human subjects. Am J Clin Nutr 63, 709-716.

Cummings JH, Macfarlane GT \& Englyst HN (2001) Prebiotic digestion and fermentation. Am J Clin Nutr 73, Suppl. 4, $15 \mathrm{~S}-420 \mathrm{~S}$.

Edwards CA \& Prrett AM (2002) Intestinal flora during the first months of life: new perspectives. Br J Nutr 88, Suppl., S11-S18.

Franks AH, Harmsen HJM, Raangs GC, Jansen GJ, Schut F \& Welling G (1998) Variations of bacterial populations in human faeces measured by fluorescent in situ hybridisation with groupspecific 16S rRNA-targeted oligonucleotide probes. Appl Environ Microbiol 64, 3336-3345.

Gee JM, Cooke D, Gorick S, Wortley GM, Greenwood RH, Zumbe A \& Johnson IT (1991) Effects of conventional sucrose-based, fructose-based and isomalt-based chocolates on postprandial metabolism in non-insulin-dependent diabetics. Eur J Clin Nutr 45, $561-566$

Gehring F \& Karle EJ (1981) Sweetening agent, Palatinit under specific consideration as to microbiological and caries-prophylactic aspects. Z Ernahrungswiss 20, 96-106.

Giaffer MH, Holdsworth CD \& Duerden BI (1991) The assessment of faecal flora in patients with inflammatory bowel disease by a simplified bacteriological technique. $J$ Med Microbiol 35, $238-243$

Gibson GR, Beatty ER, Wang X \& Cummings JH (1995) Selective stimulation of bifidobacteria in the human colon by oligofructose and inulin. Gastroenterology 108, 975-982.

Gibson GR \& Roberfroid MB (1995) Dietary modulation of the human colonic microbiota: introducing the concept of prebiotics. J Nutr 125, 1401-1412.

Gostner A, Schäffer V, Theis S, et al. (2005) Effects of isomalt consumption on gastrointestinal and metabolic parameters in healthy volunteers. Br J Nutr 94, 575-581.

Grasten SM, Juntunen KS, Poutanen KS, Gylling HK, Miettinen TA \& Mykkanen HM (2000) Rye bread improves bowel function and decreases the concentrations of some compounds that are putative colon cancer risk markers in middle-aged women and men. $J$ Nutr 130, 2215-2221.

Harmsen HJM, Elferrich P, Schut F \& Welling GW (1999) A 16S rRNA-targeted probe for detection of lactobacilli and enterococci in faecal samples by fluorescent in situ hybridisation. Microb Ecol Health Dis 11, 3-12.

Harmsen HJ, Raangs GC, He T, Degener JE \& Welling G (2002a) Extensive set of $16 \mathrm{~S}$ rRNA-based probes for detection of bacteria in human feces. Appl Environ Microbiol 68, 2982-2990.

Harmsen HJ, Wildeboer-Veloo AC, Grijpstra J, Knol J, Degener JE \& Welling GW (2000) Development of 16S rRNA-based probes for the Coriobacterium group and the Atopobium cluster and their application for enumeration of Coriobacteriaceae in human feces from volunteers of different age groups. Appl Environ Microbiol 66, 4523-4527.

Harmsen HJM, Raangs GC, Franks AH, Wildeboer-Veloo AC \& Welling GW (2002b) The effect of the prebiotic inulin and the prebiotic Bifidobacterium longum on the fecal microflora of healthy volunteers measured by FISH and DGGE. Microbiol Ecol Health Dis 14, 211-219.

Hold GL, Schwiertz A, Aminov R, Blaut M \& Flint HJ (2003) Oligonucleotide probes that detect quantitatively significant groups of butyrate-producing bacteria within the human fecal flora. Appl Environ Microbiol 69, 4320-4324.

Hütter R, Böswart F \& Irsigler K (1993) Insulinverbrauch von Typ-IDiabetikern nach oraler Gabe von Isomalt. Akt Ernähr 18, 149-154.

Hylla S, Gostner A, Dusel G, Anger H, Bartram HP, Christl SU, Kasper H \& Scheppach W (1998) Effects of resistant starch on the colon in healthy volunteers: possible implications for cancer prevention. Am J Clin Nutr 67, 136-142.
Johanson GK, Ottova L \& Gustafsson JA (1990) Shift from a mixed diet to a lactovegetarian diet: influence on some cancer-associated intestinal bacterial enzyme activities. Nutr Cancer 14, 239-246.

Kleessen B, Hartmann L \& Blaut M (2001) Oligofructose and longchain inulin influence on the gut microbial ecology of rats associated with a human faecal flora. Br J Nutr 86, 291-300.

Kleessen B, Sykura B, Zunft HJ \& Blaut M (1997) Effects of inulin and lactose on fecal microflora, microbial activity, and bowel habit in elderly constipated persons. Am J Clin Nutr 65, 1397-1402.

Kruse HP, Kleessen B \& Blaut M (1999) Effects of inulin on faecal bifidobacteria in human subjects. Br J Nutr 82, 375-382.

Langendijk PS, Schut F, Jansen GJ, Raangs GC, Kamphuis GR, Wilkinson MHF \& Welling GW (1995) Quantitative fluorescence in situ hybridisation of Bifidobacterium spp. with genus-specific 16S rRNA-targeted probes and its application in fecal samples. Appl Environ Microbiol 61, 3069-3075.

Langkilde AM, Andersson H, Schweizer TF \& Wursch P (1994) Digestion and absorption of sorbitol, maltitol and isomalt from the small bowel. A study in ileostomy subjects. Eur J Clin Nutr 48, 768-775.

Lin HC \& Visek WJ (1991) Colon mucosal cell damage by ammonia in rats. $J$ Nutr 121, 887-893.

Linskens RK, Huijsdens XW, Savelkoul PH, Vandenbroucke-Grauls CM \& Meuwissen SG (2001) The bacterial flora in inflammatory bowel disease: current insights in pathogenesis and the influence of antibiotics and probiotics. Scand J Gastroenterol 234, Suppl., $29-40$.

Livesey G (2003) Health potential of polyols as sugar replacers, with emphasis on low glycaemic properties. Nutr Res Rev 16, 163-191.

McBain AJ \& Macfarlane GT (1998) Ecological and physiological studies on large intestinal bacteria in relation to production of hydrolytic and reductive enzymes involved in formation of genotoxic metabolites. J Med Microbiol 47, 407-416.

McBain AJ \& MacFarlane GT (2001) Modulation of genotoxic enzyme activities by non-digestible oligosaccharide metabolism in in-vitro human gut bacterial ecosystems. J Med Microbiol 50 , 833-842.

Mallett AK, Rowland IR \& Farthing MJ (1987) Dietary modification of intestinal bacterial enzyme activities - potential formation of toxic agents in the gut. Scand J Gastroenterol 129, Suppl., $251-257$

Manz W, Amann R, Ludwig W, Vancanneyt M \& Schleifer K-H (1996) Application of a suite of 16S rRNA-specific oligonucleotide probes designed to investigate bacteria of the phylum cytophagaflavobacter-bacteroides in the natural environment. Microbiology 142, 1097-1106.

Manz W, Amann R, Ludwig W, Wagner M \& Schleifer K-H (1992) Phylogenetic oligodeoxynucleotide probes for the major subclasses of proteobacteria: problems and solutions. Syst Appl Microbiol 15, 593-600.

Marteau P, Seksik P \& Jian R (2002) Probiotics and intestinal health effects: a clinical perspective. Br J Nutr 88, Suppl., S51-S57.

Meier H, Amann R, Ludwig W \& Schleifer K-H (1999) Specific oligonucleotide probes for in situ detection of a major group of grampositive bacteria with low DNA G $+\mathrm{C}$ content. Syst Appl Microbiol 22, 186-196.

Menne E, Guggenbuhl N \& Roberfroid M (1997) $F_{n}$-type chicory inulin hydrolysate has a prebiotic effect in humans. J Nutr 130, 1197-1199.

Noack J, Kleessen B, Proll J, Dongowski G \& Blaut M (1998) Dietary guar gum and pectin stimulate intestinal microbial polyamine synthesis in rats. J Nutr 128, 1385-1391.

Petzoldt R, Lauer P, Spengler M \& Schoffling K (1982) Palatinite in type II diabetics. Effect on blood-glucose, serum-insulin, C-peptide and free fatty acids. Dtsch Med Wochenschr 107, 1910-1913.

Pistoli S, Smejkal C, McCartney A \& Gibson GR (2003) Differences in the faecal flora of healthy individual and patients with irritable 
bowel syndrome, and in vitro effects of a synbiotic upon gut flora composition. Clin Nutr 22, 60.

Poulsen IK, Licht TR, Rang C, Krogfelt KA \& Molin S (1995) Physiological state of Escherichia coli BJ4 growing in the large intestines of streptomycin-treated mice. J Bacteriol 177, 5840-5845.

Rao AV (2001) The prebiotic properties of oligofructose at low intake levels. Nutr Res 21, 843-848.

Roediger WE (1982) Utilization of nutrients by isolated epithelial cells of the rat colon. Gastroenterology 83, 424-429.

Roller C, Wagner M, Amann R, Ludwig W \& Schleifer K-H (1994) In situ probing of Gram-positive bacteria with high DNA G + C content using 23S rRNA-targeted oligonucleotides. Microbiology 140, 2849-2858.

Scheppach W (1994) Effects of short chain fatty acids on gut morphology and function. Gut 35, S35-S38.

Scheppach W, Luehrs H \& Menzel T (2001) Beneficial health effects of low-digestible carbohydrate consumption. $\mathrm{Br} J$ Nutr 85, Suppl. 1, S23-S30.

Schwiertz A, Le Blay G \& Blaut M (2000) Quantification of different Eubacterium spp. in human fecal samples with species-specific 16S rRNA-targeted oligonucleotid probes. Appl Environ Microbiol 66, $375-382$.

Suau A, Rochet V, Sghir A, Gramet G, Brewaeys S, Sutren M, Rigottier-Gois L \& Dore J (2001) Fusobacterium praunitzii and related species represent a dominant group within the human fecal flora. Syst Appl Microbiol 24, 139-145.

Tuohy AM, Finlay RK, Wynne AG \& Gibson GR (2001a) A human volunteer study on the prebiotic effects of HP-inulin - fecal bacteria enumerated using fluorescent in situ hybridisation (FISH). Anaerobe 7, 113-118.

Tuohy KM, Kolida S, Lustenberger AM \& Gibson GR (2001b) The prebiotic effects of biscuits containing partially hydrolysed guar gum and fructo-oligosaccharides - a human volunteer study. $\mathrm{Br}$ J Nutr 86, 341-348.

van de Kamer JH, Bokkel Ten Huining H \& Weyers HA (1949) Einfache Methode zur Bestimmung des Fettgehalts im Stuhl. J Biol Chem 177, 347-350.

Van Loo J, Cummings J, Delzenne N, et al. (1999) Functional food properties of non-digestible oligosaccharides: a consensus report from the ENDO project (DGXII AIRII-CT94-1095). Br J Nutr 81, $121-132$.

van Weerden EJ \& Huisman J (1993) The digestion process of the sugar alcohol isomalt in the intestinal tract of the pig. 1. Studies with administration of isomalt in the feed. Br J Nutr 69, 455-466.

Velazquez OC, Lederer HM \& Rombeau JL (1996) Butyrate and the colonocyte. Implications for neoplasia. Dig Dis Sci 41, 727-739.

Weber FL Jr (1997) Effects of lactulose on nitrogen metabolism. Scand J Gastroenterol 222, Suppl., 83-87.

Wheeler LA, Soderberg FB \& Goldman P (1975) The relationship between nitrogroup reduction and the intestinal microflora. $J$ Pharmacol Exp Ther 194, 135-144.

Wise A, Mallet AK \& Rowland IR (1982) Dietary fibre, bacterial metabolism and toxicity of nitrate in the rat. Xenobiotica 12,111-118.

Zhong J, Luo B, Xiang M, Liu H, Zhai Z, Ang T \& Craig S (2000) Studies on the effects of polydextrose intake on physiologic functions in Chinese people. Am J Clin Nutr 72, 1503-1509. 